\title{
Stratification Temperature Affects the In Vitro Germination of Immature Prunus Embryos
}

\author{
M.E. Daorden*, J.A. Marín and A. Arbeloa \\ Estación Experimental de Aula Dei (CSIC) \\ Apartado 202, 50080 Zaragoza, Spain \\ *Permanent address: EEA San Pedro- INTA \\ C.C. $\mathrm{N}^{\circ} 43$, (2930) Buenos Aires \\ Argentina
}

Keywords: In vitro stratification, seeds, germination, Prunus, interspecific hybrids

\begin{abstract}
The rapid multiplication of clonal plants is desirable to shorten crossing programs in fruit tree breeding. In vitro stratification and germination allowed us to shorten the time and to improve the germination rates by embryo rescue. In this work, two stratification temperatures $\left(0^{\circ}\right.$ and $\left.4^{\circ} \mathrm{C}\right)$ were compared and related to the development of interspecific hybrid embryos. The influence of embryo size was also determined, in order to optimise the process. Data showed that germination took place in $91 \%$ of the seeds when the stratification temperature was $4^{\circ} \mathrm{C}$. During stratification, embryo weight and embryo-weight increment were assessed at 30 and 60 days after sowing. Stratification temperature showed a significant effect in both embryo weight and embryo-weight increment 60 days after sowing, while embryo size showed a smaller influence. Embryo culture and stratification at $4{ }^{\circ} \mathrm{C}$ allowed a satisfactory germination of immature seeds produced in crosses from breeding programs.
\end{abstract}

\section{INTRODUCTION}

In vitro embryo germination has been successfully used in Prunus breeding programs to overcome the lack of seed viability. Blake (1939) first applied the technique in a peach breeding program and more recently it has been widely used in peach breeding for early maturation cultivars (Ramming, 1985) and seedless grape breeding (Emershad and Ramming, 1982). Post zygotic incompatibility barriers after interspecific crossing can also be overcome by in vitro embryo rescue (Ramming, 1990).

Rapid multiplication of clonal plants is desirable to shorten crossing programs in fruit tree breeding. In vitro stratification of immature embryos has allowed us to improve germination rates and to reduce the time required for developing new hybrids (Arbeloa et al., 2000; García et al. 2001; Daorden et al., 2001a).

To attain successful germination rates of seeds a cold pre-treatment is necessary to overcome dormancy and to induce shoot elongation (Hartmann et al 1990; Herrero, 1978). Stratification temperatures differ among species and environmental conditions and need to be well established for adequate seed germination. Initial embryo size is also a determinant in germination success (Burgos and Ledbetter, 1993).

In this work, two in vitro stratification temperatures are related to embryo development in vitro. Also, the influence of embryo size on germination rate is studied in order to optimise plantlet production in breeding fruit tree programs. The cultivated embryos used in the experiments came from interspecific crosses between myrobalan $\mathrm{x}$ apricot.

\section{MATERIALS AND METHODS}

Three myrobalan (Prunus cerasifera Ehrh.) clones (Mb1, Mb2, Mb3) were crossed with the apricot (Prunus armeniaca L.) cultivar 'Moniquí' (MB) by hand pollinations of emasculated flowers. Immature fruits were harvested 12 weeks after pollination.

Seeds were extracted and the embryos dissected in aseptic conditions. The 
embryos were weighed and measured before sowing in Cheé and Pool (1987) medium without growth regulators. Two temperatures, $0^{\circ}$ and $4^{\circ} \mathrm{C}$ and dark conditions were established during the stratification period.

Embryo weight was assessed at 30 and 60 days after sowing. After a period of stratification of 18 weeks, seeds were placed in a culture chamber at $24^{\circ} \mathrm{C}$ and exposed to a photoperiod of 16 hours and $35 \mu \mathrm{mol} \cdot \mathrm{m}^{-2} \cdot \mathrm{s}^{-1}$ of light intensity. Embryos were considered germinated when they developed a shoot of $5 \mathrm{~mm}$ length. Germination rate and timing were also evaluated.

\section{RESULTS}

\section{Embryo Size}

A total of 55 embryos were dissected and measured showing differences in initial size depending on the crosses (Table 1). $74.5 \%$ of embryos were 8-10 mm length and $25.5 \%$ were smaller than $8 \mathrm{~mm}$. Among these embryos, $7.3 \%$ were smaller than $3.5 \mathrm{~mm}$.

\section{Embryo Size and Stratification Temperature Influence on Embryo Weight and Embryo Weight-Increment}

Embryo weight average was different depending on the genotype. Both embryo weight and embryo weight-increment also showed differences among genotypes (Fig. 1) $M b 1 \times M B$

Embryo size at sowing time had a significant influence on all the factors studied during the stratification period. Both embryo weight at 30 and 60 days after sowing and embryo weight-increment were affected by initial embryo size (Fig. 1).

Stratification temperature, however, had only a significant influence on weight and weight-increment 60 days after sowing. Weight increments were greater at $4^{\circ} \mathrm{C}$.

$M b 2 \times M B$

For this cross, embryo initial size had no significant influence on the studied factors. We only found a significant influence of the temperature on embryo weight at 60 days after sowing. At $0^{\circ} \mathrm{C}$ there was almost no weight-increment for the embryos (Fig. 1). $M b 3 \times M B$

Embryo initial size had a significant influence on weight at 30 days after sowing but had no influence at 60 days after sowing. Temperature had a significant influence both on embryo weight and embryo weight-increment at 30 and 60 days after sowing. When initial size was smaller, we observed greater weight-increment at $4^{\circ} \mathrm{C}$ at both dates. At $0^{\circ} \mathrm{C}$ no appreciable weight-increment was observed (Fig.1).

\section{Temperature, Embryo Size and Genotype Influence on Embryo Germination}

Germination rates were influenced by stratification temperature, size and genotype of seed. Stratification temperature has a noticeable effect, since, $91 \%$ of the seeds germinated at $4^{\circ} \mathrm{C}$ and only $26 \%$ of the seeds germinated at $0^{\circ} \mathrm{C}$ (Fig. 2). Germination generally took place once the stratification period was finished and when the seeds were cultivated at high temperature $\left(24^{\circ} \mathrm{C}\right)$ and light conditions, although some of the embryos germinated during the stratification period.

Initial embryo size also had an effect on germination rates. In optimum conditions, the germination rate attained $95.6 \%$ for the seeds of embryos larger than $8 \mathrm{~mm}$ and $60 \%$ for the embryos smaller than $8 \mathrm{~mm}$.

Genotype had also an effect on germination rate. Germination rates varied between 86 and $100 \%$ at $4^{\circ} \mathrm{C}$ and between 10 and $60 \%$ at $0^{\circ} \mathrm{C}$ depending on the crosses.

Shoot and radicle emergence occurred at different times depending on stratification temperatures. For all crosses, $50 \%$ of the embryos germinated eight weeks after sowing when the stratification temperature was $4^{\circ} \mathrm{C}$. However, at $0^{\circ} \mathrm{C}$, germination took place at eighteen weeks after sowing, when the embryos were placed in the cultivation chamber at $24^{\circ} \mathrm{C}$. The process proceeded in a similar way for the three crosses. Radicle emergence occurred earlier than shoot appearance at $4^{\circ} \mathrm{C}$. 


\section{DISCUSSION}

In vitro germination of immature seeds succeeded in more than $91 \%$ of the embryos when they were stratified at $4^{\circ} \mathrm{C}$. Application of these techniques facilitated a rapid production of hybrid plantlets in a rootstock breeding program for apricot (Arbeloa et al., 2001; Daorden et al., 2001a and b).

In vitro embryo germination success depends on the maturation stage of the embryo and this can be related to embryo size (Burgos and Ledbetter, 1993). When embryo size is very small no development is attained (Pierik, 1990). Immature fruits were harvested 12 weeks after pollination and we found different embryo developmental stages and sizes at this moment. Crossing incompatibility may have caused these different developmental stages. Most of embryos were larger than $8 \mathrm{~mm}$, however, $25.5 \%$ of them were smaller than $8 \mathrm{~mm}$. Nevertheless, the average germination rate obtained was $91 \%$, which included non-viable embryos smaller than $8 \mathrm{~mm}$.

During the stratification period, embryo weight and embryo weight-increment were considered indicators of the evolution of the embryo. In this sense, both factors were affected by three characters: 1) the stratification temperature, 2) the initial embryo size and 3) the crossing combination. We observed a great influence of temperature on weight and weight-increment at 60 days after sowing. Initial embryo size showed a smaller influence on embryo weight.

In Prunus, different stratification temperatures and durations have been used; temperatures varying between $0^{\circ} \mathrm{C}$ and $5^{\circ} \mathrm{C}$ and durations between 30 and 120 days (Bassi and Infante, 1994; Burgos and Ledbetter, 1993; Chaparro and Sherman, 1994; Emershad and Ramming, 1994; Ledbetter et al., 1998). In this work we found the greatest response in embryo weight when stratification temperature was $4^{\circ} \mathrm{C}$.

Stratification temperature became a critical factor both on embryo evolution (shoot and radicle emergence) and on germination rate, as is also the case when using conventional methods (Herrero, 1978) When stratification temperature was $4^{\circ} \mathrm{C}$ germination initiated 10 weeks earlier than at $0^{\circ} \mathrm{C}$. Germination rate at the adequate temperature led to germination rates of $91 \%$ versus $26 \%$ at $0^{\circ} \mathrm{C}$

Embryo culture and stratification at $4{ }^{\circ} \mathrm{C}$ allowed a satisfactory germination of immature seeds produced in crosses of breeding programs. In vitro germination techniques, here optimised, have led to the development of an alternative method which is quicker and more reliable in developing hybrid plantlets (Arbeloa et al., 2001; Daorden et al., 2001b).

In vitro methods allow the production of increased numbers of genotypes by embryo rescue and increased numbers of plants per genotype in a shorter time period, compared to conventional methods. The breeding program has been advantageously shortened and improved by the in vitro germination and multiplication of hybrid material.

\section{ACKNOWLEDGEMENTS}

This work was supported by projects CONSID - DGA: P012/2001, CICYT: AGF98-0277-C04-01 and CICYT: AGL2001-2414-C04-01.

\section{Literature Cited}

Arbeloa, A., García, E., Daorden, M.E., Andreu, P., Marín, J.A. 2000. Germinación in vitro de semillas inmaduras de mirobolán (Prunus cerasifera Ehrh.). ITEA 21 (Ext.), 59-61

Arbeloa, A., Daorden, M.E., García, E., Marín, J.A. 2001. Successful establishment of in vitro cultures of Prunus cerasifera hybrids by embryo culture of immature fruits. Acta Hortic. (en prensa).

Bassi, D., Infante, R. 1994. Esperienze di embriocoltura nel miglioramento genetico di pesco e ciliego. Frutticoltura, 7-8, 65-70.

Blake, M.A., 1939. Some results of crosses of early ripening varieties of peaches. Proc. Amer. Soc. Hort. Sci., 37, 232-241.

Burgos, L., Ledbetter, C.A. 1993. Improved efficiency in apricot breeding: Effects of 
embryo development and nutrient media on in vitro germination and seedling establishment. Plant Cell, Tissue and Organ Culture, 35, 217-222.

Chaparro, J.X., Sherman, W.B. 1994. Culture date and germination procedure affects success of nectarine ovule and embryo culture. Fruit Varieties Journal 48, 173-175.

Cheé, R., Pool, R.M. 1987. Improved Inorganic Media Constituents For In Vitro Shoot Multiplication of Vitis. Sci. Hort., 32, 85-95

Daorden, M.E., García, E., Arbeloa, A., Marín, J.A. 2001a Aplicación de la micropropagación a la obtención de patrones híbridos para albaricoquero. Actas de Horticultura (en prensa)

Daorden, M.E., García, E., Marín, J.A., Arbeloa, A. 2001b. Obtención de híbridos interespecíficos entre ciruelo y albaricoquero mediante el cultivo in vitro de embriones inmaduros. IV Reunión de la Sociedad Española de Cultivo in vitro de Tejidos Vegetales, 5, Santiago de Compostela (España).

Emershad, R.L., Ramming, D.W. 1982. In ovulo embryo culture of Vitis vinifera L. c.v. "Thomson Seedless". HortScience 17, 576. (Abstr.)

Emershad, R.L., Ramming, D.W. 1994. Effects of media on embryo enlargement, germination and plant development in early-ripening genotypes of Prunus grown in vitro. Plant Cell Tissue and Organ Culture, 37, 55-59.

García, E., Daorden, M.E., Marín, J.A., Arbeloa, A. 2001. Cultivo in vitro de embriones inmaduros de Prunus. Actas de Horticultura. (en prensa).

Hartmann, H.T., Kester, D.E., Davies, F. 1990. En: Plant propagation. Principles and practices. Fifth Edition, 647 pp. Ed. Prentice-Hall International. Englewood Cliffs.

Herrero, J. 1978. Estratificado de huesos de ciruelo Mirobolán (Prunus cerasifera Ehrh.). An. Aula Dei, 14, 173-180.

Ledbetter, C.A., Palmquist, D.E., Peterson, S.J. 1998. Germination and net in vitro growth of peach, almond and peach-almond hybrid embryos in response to mannitol inclusion in the nutrient medium. Euphytica, 103, 243-250

Pierik, R.L.M. 1990. Cultivo de embriones, pp. 139-147. En: Cultivo in vitro de las plantas superiores. 326 pp. Ed. Mundi-Prensa. Madrid.

Ramming, D.W., 1985. In ovulo embryo culture of early-ripening Prunus. HortScience 20, 419-420.

Ramming, D.W. 1990. The use of embryo culture in fruit breeding. HortScience 25, 393398.

\section{$\underline{\text { Tables }}$}

Table 1. Percentage of embryos according to initial size and cross.

\begin{tabular}{l|c|c|c|c|c|c|} 
& $<3,5 \mathrm{~mm}$ & $\%$ & $4-7,5 \mathrm{~mm}$ & $\%$ & $>8 \mathrm{~mm}$ & $\%$ \\
\hline Mb 1 x MB & 4,0 & 13,3 & 3,0 & 10,0 & 23,0 & 76,7 \\
Mb 2 x MB & 0,0 & 0,0 & 4,0 & 40,0 & 6,0 & 60,0 \\
Mb 3 x MB & 0,0 & 0,0 & 3,0 & 20,0 & 12,0 & 80,0 \\
\hline Total & 4,0 & 7,3 & 10,0 & 18,2 & 41,0 & 74,5
\end{tabular}




\section{Figures}

4ㄷ

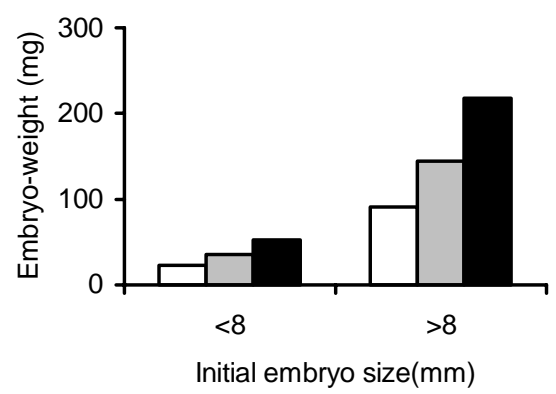

$4^{\circ} \mathrm{C}$

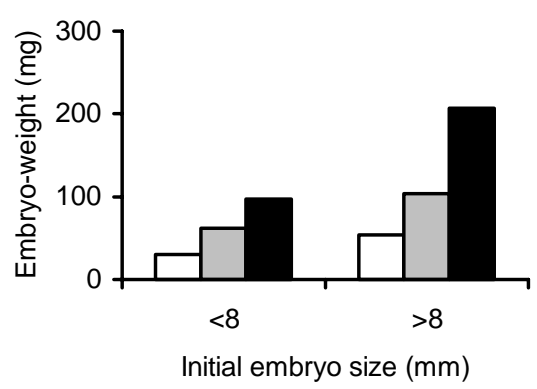

$4^{\circ} \mathrm{C}$

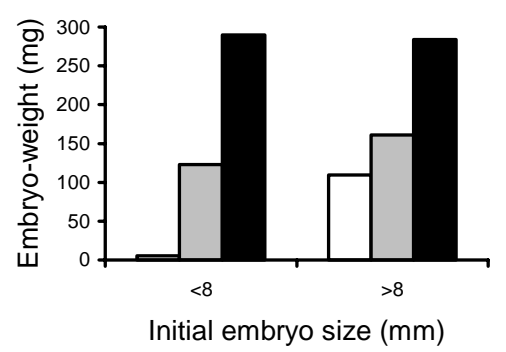

$\mathrm{O}^{\circ} \mathrm{C}$

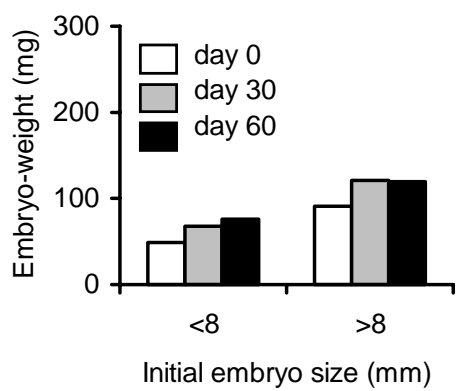

Mb1x MB

${ }^{\circ} \mathrm{O} C$

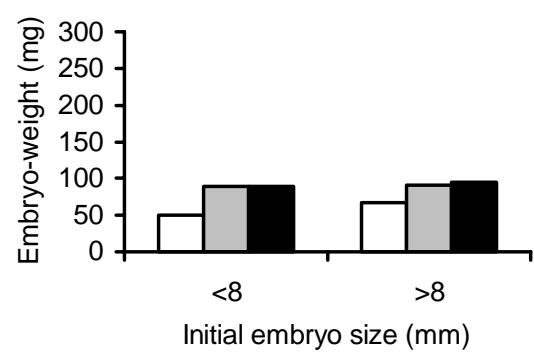

0드

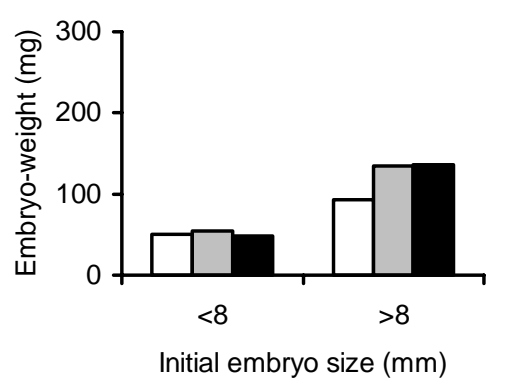

Mb3 x MB

Fig. 1. Mean weight of stratified embryos from different crosses at 0, 30, and 60 days. 


\section{In vitro embryo germination}

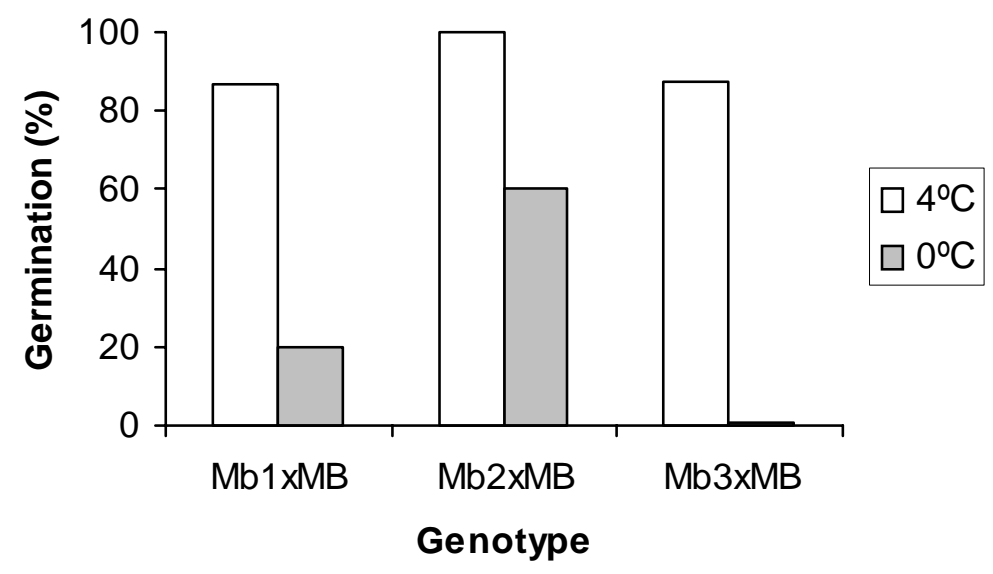

Fig. 2. Germination percentage of embryos from different crosses between myrobalan and apricot at different stratification temperatures $\left(0^{\circ} \mathrm{C}\right.$ and $\left.4^{\circ} \mathrm{C}\right)$. 